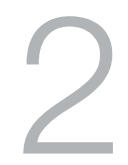

\title{
HIV, Phone Friends and Affective Technology in Papua New Guinea
}

\section{Holly Wardlow}

In the field of global health, and especially in the field of HIV treatment and care, mobile phones are primarily perceived as a technology for improving adherence to antiretroviral medications and for preventing 'loss to follow up' - that is, preventing patients' unexplained failure to return for ongoing clinical care. If, for example, one does a Google Scholar search on 'mobile phones and HIV', a typical result is 'Mobile Phone Technologies Improve Adherence to Antiretroviral Treatment in Resource-Poor Settings: A Randomized Controlled Trial of Text Message Reminders' (Pop-Eleches et al. 2011). Motivating this kind of research is the concern that, although the expanding provision of antiretroviral therapy (ART) has dramatically decreased HIV-related deaths and illness around the world, irregular or episodic treatment is the major cause of both treatment failure and the development of drug resistance. Thus, the hope is that mobile phones can improve adherence through having healthcare workers or family members text patients to remind them of upcoming or missed appointments, or to take their ART. Mobile phones are imagined instrumentally as a means for improving health outcomes through the enhanced surveillance and disciplining of patients' medication practices.

In Tari, Papua New Guinea, women living with HIV speak often of the importance of mobile phones in their lives, but never as tools for improving medication adherence. Rather, in the face of community 
stigma or family abandonment, they use mobile phones to collect 'phone friends' who may provide emotional comfort, mental diversion, romantic escapism and even material support. Phone friends can be thought of as intimate strangers - they are people met and known only by mobile phone (Andersen 2013; Jorgensen 2014). Sometimes these connections are made through friends of friends, but most often they are made through calling or accepting calls from unknown numbers. In this chapter, I first provide an overview of mobile phone use in Tari, focusing on the phenomenon of phone friends. I then explain why the sociality of women living with HIV is often severely circumscribed because of both family rejection and their own strategies for self care. I conclude with a discussion of how these women use mobile phones to achieve a more expansive and emotionally fulfilling sociality, showing that, in contrast to the domain of public health, which imagines the mobile phone as an instrumental technology, mobile phones are better understood as an 'affective technology' (Lasen 2004; Silva 2012) - a communication technology that not only mediates the expression and experience of emotion, but also opens up new forms of emotional intimacy.

The following is based on participant observation over four research periods from 2010-13 and on interviews with $28 \mathrm{HIV-positive} \mathrm{women}$ taking ART. With two-thirds of these women in mid to late middle age, the group was, on the whole, older than participants in much of the ethnographic research on either HIV or on mobile phone use; both of these areas of research have tended to focus on youth or people of early to mid-reproductive age. Nine of the women interviewed had no formal education, six had completed two or three grades of primary school, 12 had completed sixth grade or gone a year or two beyond sixth grade, and one had completed high school. Not easily able to write or not in the habit of doing so, most of my female interlocutors were using their mobile phones for calling, not texting, and none were using social media.

\section{Mobile Phones in Tari}

When I left Tari in 2006, there were no mobile phones and, indeed, few working landlines; when I returned in 2010, mobile phones were seemingly everywhere. Digicel and Bemobile were competing for customers, and a few of my friends owned two phones, one for each network. Feelings of loyalty to the nation often meant that they were rooting for Bemobile, 
a Papua New Guinean company, to succeed, but they acknowledged that Digicel offered better coverage, more possibilities for free credit and more affordable phones (Jorgensen, Chapter 3; Foster, Chapter 6). The rapid construction of mobile phone towers in the region, primarily by Digicel, was not, however, matched by an expansion of electrical power, and thus the primary challenge for mobile phone users in the Tari area has been finding ways to keep their phones charged. Tari only began to be incorporated into PNG Power's electrical network in 2012 and, even then, power was confined to the main town and was dependent on a 500 KVA generator set that ran only sporadically. ${ }^{1}$ The hospital, the small Porgera Joint Venture Community Relations office, the airport and a few stores had their own generators. Not surprisingly, then, every possible electrical outlet in these places and in government buildings was always being used to charge phones, often with a pile of waiting phones littering floors and counters. People who had no kin or friends with access to an electrical outlet were resourceful in their phone-charging strategies: in 2010, I came upon a young man on a remote, mountain road who had five $\mathrm{D}$ batteries lined up inside a bamboo tube with wires connecting the tube to his phone (the trick to charging the phone battery without destroying it, he said, was to use a mix of new and old batteries). By 2012, entrepreneurial young men had bought generators and set up charging stations in the main market that could accommodate 10 to 20 phones at a time, demanding 2 kina for a full charge.

Although I focus on the phenomenon of phone friends in this chapter, my female friends and interviewees knew most of their phone contacts. Women took great pleasure and comfort, for example, in being able to speak to their children who were away at boarding school or to mothers and sisters living elsewhere, often at night before bed, asking what had been eaten for dinner and sharing a prayer or blessing. In a virilocal society where it is the wife who moves to her husband's clan territory upon marriage, it is not surprising that mobile phones have been valued by women primarily for allowing them to maintain intimate contact with close female kin (see also Tacchi, Kitner and Crawford 2012). This is acutely so among the Huli, where a wife is expected to ask her husband's permission to leave the household, and a woman's female kin are often discouraged from visiting (Wardlow 2006). Mobile phones have facilitated a degree of post-marital

1 Before 2012, the town relied on a small hydropower station that was built and maintained by missionaries in the 1980s; by the early 2000s, it was in disrepair and not easily fixed. 
contact between wives and their natal kin that was never before possible. In other words, mobile phones can overcome not only the spatial distance created by physical geography, but also the socio-spatial distance created through gendered relations of power and rules of propriety.

Most of my interlocutors - male and female - had a number of phone friends in addition to their known contacts. Phone friends, as Andersen observes, may be 'a uniquely PNG response to the communicative possibilities of the mobile phone' (2013: 319). Phone friend calling is the calling of unknown phone numbers with the aim of forming a friendship or romance with a stranger that will likely exist only by phone and may endure for one phone call or for many months. The calling usually takes place at night and seems to be initiated more by men than by women. On seeing an unfamiliar number appear on the screen, women can choose to answer and converse with the caller or not. Of course men, searching for a phone friend, often end up calling other men, or they encounter female call recipients who yell or swear at them. Thus, some male friends showed me how they would make systematic lists of numbers and cross the unsuccessful ones off to ensure that they didn't call those again. And, much as Andersen describes, phone friendships are often heterosexual, romantic liaisons in which women 'let themselves be contacted by unknown men, passing long evenings entertaining them with stories about their daily lives, or with teasing, flirtation, and jokes' (2013: 319).

One of the characteristics of phone friend relationships in Papua New Guinea - and a characteristic that gives phone friendships their titillating pleasure - is that it is understood that either or both parties may be lying about who they are. As Andersen notes, 'there is not normally an expectation of sincerity in mobile phone interactions' (2013: 323). For example, one of my male friends would tell his female phone friends that he was a powerful and wealthy landowner with claims to the ExxonMobil Liquefied Natural Gas (LNG) project area, which was not true. When I expressed scepticism that he would do such a thing, he carried out a phone friend call in front of me using his wealthy landowner persona. He told me that he had once come very close to luring a nursing student to Tari all the way from the coastal town of Madang - she made it to Mt Hagen, he said, before caution got the better of her and she turned around. But, he acknowledged, he didn't really know if she had actually come as far as Mt Hagen - indeed, he didn't really know if she ever got on the bus at all, if she was actually a nursing student, or even if she really lived in Madang. This, he said, was one of the pleasures of phone friends 
- he might be getting the better of her and playing her for a fool, or she might be getting the better of him and playing him for a fool, or they might both be assuming feigned identities when speaking to each other, and neither of them ever had to know, and perhaps never could know, the truth of the situation.

The LNG project was in its development phase at that time and landowners within the project area were receiving millions of kina in small business development grants, preferential employment and subcontracts; consequently, outsiders were flooding into the area, many of them women hoping to cement relationships with these landowners. So, although unlikely, it was not out of the realm of possibility that a young woman, believing my friend's assertions, might abandon her situation and make the two- to three-day journey to find him. And, even in recollection, he experienced a frisson of both glee and terror that his nursing student might exit the realm of mobile phone fantasy and show up at his door. These elements of secrecy, deception and uncertainty, and the deliberate forestalling of definitive knowledge, have been emphasised in some of the ethnographic literature about mobile phone communication. Archambault, for example, writing of impoverished, peri-urban youth in Mozambique, asserts that mobile phones help to 'preserve and reproduce epistemologies of ignorance or modes of knowing that privilege pretense over truth and transparency' (2013: 89). In her case, young women juggle relationships with a number of different men through deceptions made possible by mobile phone communication in which one cannot actually know where the other person is, what she is doing or with whom.

My friends' stories of their phone friend inventions suggest not only a desire to pretend to be someone else for a moment, or to produce false or uncertain knowledge in another, but also to distance oneself even as one cultivates new intimacies with another. In other words, mobile phones enable hitherto impossible affective relationships with strangers across the nation, but simultaneously allow callers to maintain a safe social distance through deception. Given their tacit mutual knowledge about possible deception, phone friends are not likely to make significant requests of one another, or at least not likely to expect that the other will actually meet such a request: a phone friend might affectionately tease you, listen to your confidences without judgement, or ask you to send phone credit, but he or she will not ask you to assist with a bride wealth payment, plane 
fare or school fees. And, if he or she does, you can delete and block the number and find a new phone friend who will stay within the bounds of an affective intimacy free from social or material obligation.

Gilbert has similarly observed in her study of young women in Nigeria that 'mobile phones allow young women to stay connected while apart ... mobile communication allows young women to cope with the fears of social proximity by maintaining distance' (2016: 4, her emphasis). In her case, she found that in a context where young women were competing for jobs, admission to universities and influential social connections, their face-to-face relationships with each other 'were often tainted with acrimony, jealousy, and backstabbing behavior' (2016: 3); the desire for an intimate best friend warred with the knowledge that such intimacy exposed one to possible treachery. Mobile phone relationships with myriad barely known acquaintances offered a middle path, and she found that many of her young female interlocutors preferred to spend their time alone in their rooms, but always in touch with their dozens of mobile phone contacts.

Although my female interlocutors did not suffer the same fears about their face-to-face relations, they did say that phone friends were gratifying because one could simply 'share stories' about one's life and 'they won't ask you for anything'. This was in contrast to relations with kin or boyfriends who would inevitably ask for money, a pig or sex. In other words, what might be most interesting about the phone friend phenomenon are the desires animating this practice, one of which seems to be for a relationship that is not easy to find face-to-face and close to home - the intimate other who is affectively present, but does not enmesh one in the thick obligations of kinship, or the anxiety and anger that these heavier relations can entail. Speaking more specifically about romantic phone friendships, one female friend of mine asserted, 'Phone friends are better than friends who are there - action-action friends. Phone friends are very important. Very important. You can talk to them, laugh with them, they might send you money, and there's no action'. In comparing boyfriends with male phone friends, 'action-action' referred primarily to expectations for sex. Having male phone friends was a way of obtaining male attention, affection and perhaps even some material support (though at that time, one could only send phone credit, not money, via mobile phone), without having to engage in unwanted sex. The more we talked about her life history and 'action-action' male friends, however, the more it became clear that 'action-action' also referred to the larger encompassing domain of 
male-dominant and often coercive gender relations. When one considers the degree of corporeal violence that PNG women often experience in heterosexual relations (Jolly, Stewart and Brewer 2012), it is not so surprising that some might find disembodied phone friends preferable.

\section{HIV, Stigma and Social Contraction}

The phone friend relationships of the HIV-positive women I interviewed differed somewhat from those of other people, and these differences stemmed from their strategies for managing HIV-related precarity, worry and loneliness. People living with HIV/AIDS (PLWHA) in Papua New Guinea have experienced exclusion, isolation and even violence; the condition is associated with both sexual immorality and death, and is sometimes said to be God's punishment for sexual sin (Eves 2008; Hammar 2010; Kelly-Hanku, Aggleton and Shih 2014; Wardlow 2008, 2017). In Tari, AIDS is also associated with an abject and frightening body. As one woman said about the day she was diagnosed:

Some of the hospital staff said that it was too late, that there was nothing they could do for me, that my kin should wait for me to die and then bury me at the edge of the family cemetery. (At the edge?) Yes, lots of people think you need to bury people who die of AIDS in the wilderness or at the very margin of a family property, far away from everyone. (Why? Because they are scared of getting HIV?) Well, some are afraid of this, but many are afraid that AIDS will make the body rot in a dangerous way. Or they are afraid to look at the face of someone who died of AIDS because they are often so thin, so wasted. They are scared to look at them, afraid to smell them, afraid even to look at their graves - afraid that their spirits will be shocked if they behold them.

The availability of free ART in Tari since 2007, along with widespread AIDS education, has dramatically changed how PLWHA are treated by others, and 19 of the 28 women I interviewed spoke of being supported and nurtured by their families. Emblematic of this social acceptance was the common assertion that others were willing to 'finish my can of Coca Cola' - in other words, willing to put their lips where the woman's lips had been and to consume a beverage that might contain some of her saliva. Some of the women I interviewed, however, had been treated brutally by their families. One young mother, for example, was homeless: upon learning of her diagnosis, her family violently evicted her (she showed me the machete scars on her shoulders and back), and she and her two 
young children often slept under a tarp in sweet potato fields. Another woman, who had lived in her own small house on her brother's land, had this house burned down with all her clothing and bedding inside, and she likewise was evicted. Less brutally, many families permitted their HIVpositive family member to remain in the extended family compound, but they were expected to eat and sleep in their own small house, and sometimes expected to provision and cook for themselves, which was occasionally impossible if they had health setbacks. In other words, they were not driven off, but they were made to feel that they were a danger to the household.

Consequently, many of the women were in economically precarious situations and had found their social lives far more circumscribed than before. They were not necessarily socially isolated or excluded - some continued to sell produce at market, for example, and many regularly attended church - but they had experienced a contraction in their social networks. There were a number of different reasons for this social contraction. One young woman, for example, had been raped when a gang held up her PMV (public motor vehicle) at gunpoint, and she had become fearful about leaving her household. Other women spoke of being worried about running into kin who might snub or shame them in public. Some worried about accepting others' generosity and being unable to reciprocate because of a reduced ability to do agricultural work, and so they chose to narrow their circle of relations. A common fear was that they might encounter people who would make them angry or distressed by insulting them or reminding them of a past altercation or unresolved debt. During their HIV counselling, they had learned that they should avoid both worry and anger because these two emotions could 'wake up the virus' or give it the strength to 'break the fence' that ART had built around it. Many of them had known people who had been taking ART and died anyway, and they often attributed these deaths to excessive worrying or anger - either the emotions themselves, especially worry, had killed their bearers, or the emotions had roused and disturbed the virus, so that it was able to wreak havoc unchecked. When the women themselves developed rashes, coughs or a persistent fever, they would often attribute these symptoms to a lack of vigilance about controlling negative emotions. One strategy for avoiding dangerous feelings was to limit one's exposure to the social situations that might provoke them. Much like Gilbert's interlocutors who stayed in their rooms in order to avoid the possible 
treacheries that face-to-face intimacies could entail, some of the women I interviewed stayed within their households in order to avoid the worry or anger that might result from venturing outside.

\section{Phone Friends among Women Living with HIV}

All of the HIV-positive women I interviewed who had mobile phones (and approximately one-third of them did not) had phone friends, though the nature of these friendships differed from what Andersen (2013) found in her research with younger, more educated, urban women. For example, Andersen notes that she never heard of women initiating phone friend calls, and she characterises phone friendships as heterosexual and often romantic. In contrast, in addition to having a few male phone friends, many of the women I interviewed had female phone friends, and they themselves had initiated some of these friendships by calling unknown numbers, often at night when feeling abandoned, lonely, worried or desperate about where the next day's food, water or firewood might come from. A couple of them had acquired phone friends not by making or accepting random number calls, but by calling the contacts on used phones (probably stolen) that they had bought cheaply on the street.

I provide one example here. Last Minute Lucy, who looked to be in her early 50 s, was sometimes cruelly teased by family members for 'catching AIDS at the last minute', by which they meant at a later stage in life when most people think a woman's sexual activity should be winding down or over. She'd had a disastrous first marriage when she was much younger and, after having been beaten and repeatedly infected with gonorrhoea by her husband, she'd left him and gone through a period of 'passengering around' (having casual sex with multiple partners, sometimes in exchange for money; see Wardlow 2006). She soon tired of this lifestyle, however, and moved into her older brother's household. Dependent on him for land and a home, she had dutifully cooked and cleaned for the household, and she said she hadn't had sex for 40 years. Given my estimation of her age, this did not seem likely, and I understood this statement as signifying both a very long time and, with its possible gesture towards the Jews wandering in the wilderness for 40 years, a kind of self-imposed penance for her earlier unrestrained ways. 
And then, at the last minute, my brother hit me. (Why?) He didn't like the way I'd prepared his dinner. I'd been caring for his household for years, and then one night he lost his temper about having to eat sweet potato all the time, and he hit me. So I left. I decided to passenger around again ... I befriended a man, I went home with him, and I caught AIDS.

According to her, after her many years of abstinence, she'd had sex with only this one partner, and he had infected her with HIV. When he began to show symptoms, she insisted that they both be tested and, upon being diagnosed positive, they began a regimen of ART. He did not live his life as the nurses had instructed, however; he took his medication irregularly and continued to drink and sleep around. Lucy left him, saying that he was causing her too much stress and worry, and she was concerned that the negative emotions he provoked in her would render her antiretroviral drugs ineffective. Her older brother refused to take her back in, however, and when I met her in 2012 she was struggling to live on her own on some land her younger brother had made available to her.

When her first husband learned that she was HIV-positive and that her family had refused to take her in, he gave her some money and a used mobile phone. There were still numbers stored in its memory and, one night, in a moment of despair, when she hadn't eaten for two days, did not feel she had the strength to leave her house and was considering suicide, she started calling the numbers. A few of them didn't work, a few people yelled at her and disconnected and then one woman, Angela, answered and agreed to speak with her. It turned out Angela lived in a town about a day's drive away, had attended AIDS awareness workshops and was a devout Christian. She responded to Lucy's despair with compassion, but also reminded her that her situation was part of God's plan. And the next day she sent Lucy some food, second-hand clothing and money with a PMV driver coming to Tari. When I interviewed Lucy she had never met Angela, but they continued to call one another, and Angela still occasionally sent small gifts to her. Angela's generosity towards a complete stranger who had reached out to her by phone in the middle of the night had confirmed for Lucy that her situation was, in fact, somehow part of God's plan: God had used Angela as his instrument (his mobile phone, one might say, or at least his affective technology, restoring her feelings of hope), and she must therefore persevere and not give in to despair.

When I saw Lucy again a year later, she was in anguish because her phone had been stolen; 'tingting bilong mi fucked up', she said (my thoughts are fucked up). She had come to depend on Angela and her other phone 
friends - male and female - for emotional nurturance. When she found herself 'tingting plenti' (thinking a lot), 'wari wari' (worrying a lot) or 'busy tumas' (very busy, but it can also mean overly preoccupied with or perseverating about something), she would call them and they would help her calm down or distract her with teasing, chatty discourse. Her phone friends were, in effect, affective regulators, helping her to modulate her anxious thoughts and emotions. And, since such emotions were thought to strengthen HIV and reduce the effectiveness of ART, these friends were, from her perspective, also helping to keep the virus in check. The mobile phone, as affective technology, was thus working simultaneously as a therapeutic technology (but not in the way imagined by global health practitioners), which, to her mind, was equally important as her daily medications. Since she'd never met these friends face-to-face, she had no way of retrieving their numbers or restoring these relationships and she was feeling their loss and her mounting anxiety acutely:

All those phone friends, in Port Moresby, Mt Hagen, and other places, they would send me credit, and we talked all the time, every night, and now I don't have a phone, and I've lost all those numbers. It's terrible. I can't stop crying about it. I had the same phone for four years, and had so many numbers, so many friends. And now it's all gone.

Lucy's story of her encounter with Angela is probably the most dramatic of the phone friend stories I heard, with its intimation of possible divine intervention into the dark night of the soul, though a number of the women I interviewed similarly asserted that, when they managed to establish a phone friendship with a kind stranger somewhere in Papua New Guinea, they took it as a sign that God was reaching out to them and affirming the value of their continued life. And, like Lucy, many of the women I interviewed said that they were candid with phone friends, male and female, about their HIV-positive status. Since, as discussed above, people often emphasise the possibilities for dissimulation offered by the mobile phone and since most of the women had experienced some kind of rejection or stigma because of their HIV status, this candour might seem unusual. There are a number of reasons for their frank self-exposure. For one, many of them felt both an ethical and self-protective compulsion to disclose their status to their family members, congregations and larger community (Wardlow 2017); I was repeatedly told, 'Everyone knows, everyone in my community knows'. Health workers encourage people living with HIV to disclose their status, at least to spouses and close family members, and many are reluctant to provide ART to patients 
whose family members don't accompany them to their appointments or who show other signs of hiding their status from close kin. They worry both that these patients do not have adequate social support and that they are not 'reliable' - the euphemistic word they often used to describe patients who might be engaging in unprotected sex or other practices (e.g. gambling, carousing, eating greasy street foods instead of garden produce) that indicate an unwillingness to abide by the expected behaviour of an AIDS patient. Moreover, the women I interviewed knew that, for some community members, not disclosing one's HIV-positive status was equivalent to hiding it and might lead to the suspicion or even accusation that one was 'giaman olsem normal (pretending to be normal), engaging in unprotected sex and infecting innocent others. The only way to prevent others' misgivings about one's possible malevolent actions was to disclose assertively and widely. This imperative to disclose might, for some women, be internalised so powerfully that it holds true even with their phone friends, whom they will likely never meet. Perhaps more important, however, is that their phone friends provide them with vital affective sustenance. Since affective regulation and relief is what many of them seek from phone friends, candour about their HIV status is necessary - without it they cannot confide their specific miseries and have them soothed.

\section{Conclusion}

Mobile phones can be conceptualised as an affective technology that enters social contexts characterised by specific gendered relations of power and potentially changes them, enabling, for example, closer contact between married women and their natal kin, or romantic heterosexual relations free from coercive or violent corporeality. Further, the pleasures and possibilities of phone friendships in Papua New Guinea may include not only the creation of a fantasy space in which one can, without repercussion or expectation, pretend to be someone else, but also the creation of an affective or therapeutic space in which one can, also without repercussion or expectation, be fully candid about oneself. For HIV-positive women in Tari, mobile phones are clearly more than tools for improving adherence to pharmaceutical and clinical regimes. Women whose networks have been circumscribed by stigma can use them to expand their social worlds, often finding affective sustenance that has been withdrawn following their diagnosis. And, while these relationships 
are sometimes heterosexual, flirtatious and romantic in nature, they are also sometimes homosocial relations in which women can confide their anxieties and receive compassion, advice and emotional solace.

\section{Acknowledgements}

This research was funded by SSHRC Standard Research Grant \#331985. I thank Professor Betty Lovai of the University of Papua New Guinea, and the health workers who helped to facilitate this research, especially Martha Parale; and Jethiro Harrison and Ruben Enoch, who were University of Papua New Guinea student interns with me in 2013.

\section{References}

Andersen, B. 2013. Tricks, Lies, and Mobile Phones: 'Phone Friend' Stories in Papua New Guinea. Culture, Theory and Critique, 54(3): 318-34. doi.org/10.1080/14735784.2013.811886

Archambault, J.S. 2013. Cruising through Uncertainty: Cell Phones and the Politics of Display and Disguise in Inhambane, Mozambique. American Ethnologist, 40(1): 88-101. doi.org/10.1111/amet.12007

Eves, R. 2008. Moral Reform and Miraculous Cures: Christian Healing and AIDS in New Ireland, Papua New Guinea. In Making Sense of AIDS: Culture, Sexuality, and Power in Melanesia. L. Butt \& R. Eves, eds. Honolulu: University of Hawai'i Press, pp. 206-23.

Gilbert, J. 2016. 'They're My Contacts, Not My Friends': Reconfiguring Affect and Aspirations Through Mobile Communication in Nigeria. Ethnos, 83(2): 237-54. doi.org/10.1080/00141844.2015.1120762

Hammar, L. 2010. Sin, Sex and Stigma: A Pacific Response to HIV and AIDS. Wantage: Sean Kingston Publishing.

Jolly, M., C. Stewart \& C. Brewer, eds 2012. Engendering Violence in Papua New Guinea. Canberra: ANU E Press. 
Jorgensen, D. 2014. Gesfaia: Mobile Phones, Phone Friends, and Anonymous Intimacy in Contemporary Papua New Guinea. Paper presented at CASCA: Canadian Anthropology Society Conference. York University, Toronto, 30 April.

Kelly-Hanku, A., P. Aggleton \& P. Shih 2014. 'We Call It a Virus but I Want to Say It's the Devil Inside': Redemption, Moral Reform and Relationships with God among People Living with HIV in Papua New Guinea. Social Science \& Medicine, 119: 106-13. doi.org/10.1016/j. socscimed.2014.08.020

Lasen, A. 2004. Affective Technologies - Emotions and Mobile Phones. Receiver, 11. robertoigarza.files.wordpress.com/2009/07/art-affectivetechnologiese28093emotionsmobile-phones-lasen-2006.pdf (accessed 14 April 2018).

Pop-Eleches, C., H. Thirumurthy, J.P. Habyarimana, J.G. Ziven, M.P. Goldstein, D. de Walque, L. MacKeen, J. Haberer, S. Kimaiyo, J. Sidle, D. Ngare \& D. Bangsberg 2011. Mobile Phone Technologies Improve Adherence to Antiretroviral Treatment in Resource-Poor Settings. AIDS, 25(6): 825-34. doi.org/10.1097/QAD.0b013e32834380c1

Silva, S.R. 2012. On Emotion and Memories: The Consumption of Mobile Phones as 'Affective Technology'. International Review of Social Research, 2(1): 157-72. doi.org/10.1515/irsr-2012-0011

Tacchi, J., K. Kitner \& K. Crawford 2012. Meaningful Mobility: Gender, Development and Mobile Phones. Feminist Media Studies, 12(4): 528-37.

Wardlow, H. 2006. Wayward Women: Sexuality and Agency in a New Guinea Society. Berkeley: University of California Press.

2008. 'You Have to Understand: Some of Us Are Glad AIDS Has Arrived': Christianity and Condoms among the Huli, Papua New Guinea. In Making Sense of AIDS: Culture, Sexuality, and Power in Melanesia. L. Butt \& R. Eves, eds. Honolulu: University of Hawai'i Press, pp. 187-205.

2017. The (Extra)ordinary Ethics of Being HIV-Positive in Rural Papua New Guinea. Journal of the Royal Anthropological Institute, 23(1): 103-19. doi.org/ 10.1111/1467-9655.12546 
This text is taken from The Moral Economy of Mobile Phones: Pacific Islands Perspectives, edited by Robert J. Foster and Heather A. Horst, published 2018 by ANU Press, The Australian National University,

Canberra, Australia.

doi.org/10.22459/MEMP.05.2018.02 